\title{
Vitellogenin and vitellogenin receptor gene expression and 20-hydroxyecdysone concentration in Macrobrachium rosenbergii exposed to chlordecone
}

\author{
Anne Lafontaine ${ }^{1}$. Marc Hanikenne ${ }^{2,3}$. Céline Boulangé-Lecomte ${ }^{4}$. \\ Joëlle Forget-Leray ${ }^{4}$ Jean-Pierre Thomé ${ }^{1} \cdot$ Eric Gismondi $^{1}$
}

Received: 29 February 2016 / Accepted: 15 July 2016

(C) Springer-Verlag Berlin Heidelberg 2016

\begin{abstract}
Chlordecone is a persistent organochlorine pesticide widely used in Guadeloupe (French West Indies) to control the banana weevil Cosmopolites sordidus. Although it was previously highlighted that chlordecone may affect the reproduction and growth of vertebrate species, little information is available on the chlordecone effects in invertebrates. The present study investigated the effects of chlordecone on a hormone and a protein having key roles in reproduction and growth of the decapod crustacean Macrobrachium rosenbergii, by measuring the 20-hydroxyecdysone concentration, vitellogenin, and vitellogenin receptor gene expression, as well as the bioconcentration of chlordecone in exposed prawns. First, the results revealed that chlordecone was accumulated in M. rosenbergii. Then, it was found that $\mathrm{Vg}$ and $\mathrm{VgR}$ gene expression were increased in male and female M. rosenbergii exposed to chlordecone for 90 and 240 days, while the 20hydroxyecdysone concentrations were decreased. This work suggests that chlordecone accumulates in prawn tissues and could affect key molecules involved in the reproduction and
\end{abstract}

Responsible editor: Cinta Porte

Anne Lafontaine

anne.lafontaine@ulg.ac.be

1 Laboratory of Animal Ecology and Ecotoxicology (LEAE), Centre of Analytical Research and Technology (CART), University of Liège, 15 Allée du Six Aout, 4000 Liège, Belgium

2 Center for Protein Engineering, Functional Genomics and Plant Molecular Imaging, University of Liège, 27 Boulevard du Rectorat, 4000 Liège, Belgium

3 PhytoSYSTEMS, University of Liège, 27 Boulevard du Rectorat, 4000 Liège, Belgium

4 Normandie University, ULH, UMR I-02 SEBIO, FR CNRS 3730 SCALE, 25 rue Philippe Lebon, 76058 Le Havre, France the growth of the invertebrate M. rosenbergii. However, many questions remain unresolved regarding the impacts of chlordecone on growth and reproduction and the signaling pathways responsible for these effects, as well as the potential role of confounding factors present in in situ studies.

Keywords Macrobrachium rosenbergii · Chlordecone · Vitellogenin · Vitellogenin receptor · 20-Hydroxyecdysone

\section{Introduction}

Studies on the impacts of endocrine-disrupting compounds (EDCs) on wildlife have focused mainly on hormonal regulation related to reproduction and development processes which have critical roles in population dynamics (Arukwe and Goksøyr 2003; Gismondi and Thomé 2014; Jubeaux et al. 2012). Indeed, many pollutants in aquatic environment are able to interfere with the endocrine system of exposed organisms which could lead to dysfunctions of biological processes (e.g., growth, reproduction) (Hyne 2011). Endocrine disruption has been extensively described in aquatic vertebrates (Kortenkamp et al. 2011; LeBlanc 2007), and the best known marker is vitellogenin $(\mathrm{Vg})$ which has been used as exposure biomarker in several vertebrate species due to its key role in the reproduction and its induction via the control of the estrogen receptor pathway (Jones et al. 2000; Sumpter and Jobling 1995; Tyler et al. 1996; Zhong et al. 2014). However, Thornton et al. (2003) suggested that ecdysozoans lost the steroid receptor family, and Thomson et al. (2009) underlined the absence of receptors of the 3A group (estrogen receptor) and the $3 \mathrm{C}$ group (androgen, progestogen receptors) in Daphnia pulex. Therefore, although invertebrates can also be exposed to known EDCs in vertebrates, it is still difficult to make assumptions about the 
impacts of EDCs on invertebrates using knowledge from vertebrate species (Scott 2013). Investigations are thus necessary to improve our understanding of the metabolic pathways involved in the disruption of the endocrine functions in invertebrates.

Chlordecone (CLD) was an insecticide commonly employed in the French West Indies (FWI) in Guadeloupe to control the banana weevil Cosmopolites sordidus from 1972 to 1993. Chlordecone is an organochlorine compound that acts by altering the sodium channels, essential for the transmission of nerve impulses in organisms (Guzelian 1982; Newhouse et al. 2009). This inhibition of the sodium channels induces an increase of the intracellular concentration of calcium which activates the contractile proteins and causes convulsions and death of the target insect. As CLD interferes with the nervous system, it is considered a neurotoxic substance.

A few years after its introduction, widespread pollution of soils, rivers, wild animals, and aquatic organisms was reported (Cavelier 1980; Snegaroff 1977). Indeed, because of its high Koc (soil organic carbon water partitioning coefficient), Kow (octanol-water partition coefficient), and its affinity for lipids, CLD is persistent in the environment and accumulates in the food web (Cabidoche and Lesueur-Jannoyer 2012). Since Hammond et al. (1979) demonstrated that CLD can bind to estrogen receptor in rat, many studies investigated the endocrine effects of CLD in various biological models. However, in aquatic ecosystems, endocrine effects of CLD were mainly studied in vertebrate models. For example, Donohoe and Curtis (1996) observed an increase of the Vg concentration in juvenile rainbow trout Oncorhynchus mykiss exposed for 33 weeks to CLD. Moreover, Curtis and Beyers (1978) observed a decrease of the oviposition of the teleost Oryzias latipes after $252 \mathrm{~h}$ of CLD exposure. Until now, few studies have been carried out in invertebrate models to investigate the toxic effects of CLD. Nevertheless, Gaume et al. (2014) highlighted that a CLD exposure caused the induction of genes involved in the anti-oxidative defense (e.g., catalase and glutathione peroxidase) or in the biotransformation process (i.e., cytochrome P450 and glutathione-S-transferase). Giusti et al. (2014) showed the reduction of the oviposition and the fecundity of the gastropod Lymnaea stagnalis exposed to CLD at environmental relevant concentrations. Finally, our previous study showed that CLD exposure in laboratory affected the 20-hydroxyecdysone concentration (i.e., molting hormone) and the chitobiase activity (i.e., molting enzyme), both controlled by the endocrine system, in the decapod Macrobrachium rosenbergii, suggesting that CLD could be an EDC in invertebrates (Lafontaine et al. 2016).

According to previously cited studies, CLD is suspected to be an EDC in invertebrates and could thus affect the reproduction and development. The present in situ study aimed to investigate the effects of an environmental concentration of CLD on the endocrine system of the decapod $M$. rosenbergii, which is one of the most important resources in Guadeloupe and which can be considered a good model for the wild Macrobrachium spp. living in freshwater ecosystems of these regions, by evaluating the relative expression of the vitellogenin protein $(\mathrm{Vg})$ gene. As Vg needs receptors to cross the cell membrane and exert its role in the gonadal tissue, the relative expression of the vitellogenin receptor gene ( $\mathrm{VgR}$ ) was also assessed. In parallel, since the 20-hydroxyecdysone (20-HE) synthesis is linked to the induction of the $\mathrm{Vg}$ synthesis (Hyne 2011), the concentration of 20-HE was also assessed. Finally, to incriminate the observed effects to the CLD exposure, the CLD concentrations were measured in exposed and non-exposed prawns.

\section{Materials and methods}

\section{In situ chlordecone exposure and sampling}

Post-larvae of $M$. rosenbergii were provided by a hatchery farm (OCEAN-SA, Guadeloupe, FWI) in a geographic area free of CLD contamination. Pretests have previously been carried out to evaluate the presence of CLD in tissues of prawns from the hatchery farm, and results showed no contamination (concentrations below detection limit) (data not shown). Prawns were transferred into two farming ponds, naturally filled by rivers. The first, called "control site," was located in Pointe-Noire (North Basse-Terre, Guadeloupe: $16^{\circ} 2249 \mathrm{~N}, 61^{\circ} 7769 \mathrm{~W}$ ), and the second one, called "contaminated site," was located in Saint-Claude (South Basse-Terre, Guadeloupe: 16 0193 N, 61 $6837 \mathrm{~W}$ ), which is a pond supplied by the Rivière Aux Herbes, a CLD-contaminated river $\left(0.33 \mu \mathrm{g} \mathrm{L}^{-1}\right.$ average measured between 2003 and 2008 by DIREN Guadeloupe (2003)). The farm based in Pointe-Noire is still in operation, while the Saint-Claude farm has had to cease operations because the CLD concentration in prawns was higher than the French and European maximum residue limit of $20 \mathrm{ng} \mathrm{g}^{-1}$ wet weight (Anon 2008; Ministère de l'Écologie du Développement durable et de l'Énergie 2015a). Water temperature, $\mathrm{pH}$, and dissolved oxygen were measured throughout the experiment, which took place from March 2012 to November 2012 (Table 1). These values are in accordance with optimal water

Table 1 Water parameters of Pointe-Noire (control site) and SaintClaude (contaminated site) measured during the 240 days of exposure

\begin{tabular}{lll}
\hline Parameter & Pointe-Noire & Saint-Claude \\
\hline CLD concentration $\left(\mu \mathrm{g} \mathrm{L}^{-1}\right)$ & $<\mathrm{LOD}$ & $0.33 \pm 0.10$ \\
Temperature $\left({ }^{\circ} \mathrm{C}\right)$ & $27.64 \pm 1.65$ & $27.66 \pm 1.76$ \\
$\mathrm{pH}$ & $8.47 \pm 0.47$ & $8.00 \pm 0.47$ \\
Dissolved oxygen $\left(\mathrm{mg} \mathrm{L}^{-1}\right)$ & $7.18 \pm 1.72$ & $6.44 \pm 2.46$ \\
\hline
\end{tabular}


temperature, $\mathrm{pH}$, and dissolved oxygen commonly used in prawn farms (New 2002).

After 90 and 240 days of exposure, 20 females and 20 males were collected in each site. For each gender, five prawns (corresponding to five replicates) were used for the CLD bioconcentration assessments, five prawns (corresponding to five replicates) were used to measure the 20-HE concentration, and ten prawns (corresponding to ten replicates) were used to measure the vitellogenin $(\mathrm{Vg})$ and the vitellogenin receptor (VgR) gene relative expression. The Vg gene expression was measured in hepatopancreas since this organ is one of the main synthesis sites of $\mathrm{Vg}$ in the giant freshwater prawn M. rosenbergii (Soroka et al. 2000), while the synthesis site of VgR is the gonadal tissue (Roth and Khalaila 2012). The CLD concentration was also measured in both control and exposed prawns. After sampling, individuals were transferred to the laboratory where hepatopancreas and gonadal tissue were immediately dissected, frozen in liquid nitrogen, and stored at $-80{ }^{\circ} \mathrm{C}$ until analysis. Before dissections, body length and body weight were measured and no significant difference ( $p>0.05$ of the two-way ANOVA test) was observed between individuals from the control site and those of the contaminated site, taking into account time exposure (i.e., 90 days PointeNoire, $10.20 \pm 0.52 \mathrm{~cm}$ and $10.21 \pm 1.74 \mathrm{~g}$; Saint-Claude, $10.96 \pm 0.45 \mathrm{~cm}, 15.00 \pm 3.16 \mathrm{~g} ; 240$ days Pointe-Noire, $12.03 \pm 0.97 \mathrm{~cm}, 21.79 \pm 4.18 \mathrm{~g}$; Saint-Claude, $12.72 \pm$ $0.74 \mathrm{~cm}, 23.42 \pm 4.74 \mathrm{~g}$ ). Individual sex was confirmed during dissections, thanks to the observation of gonadal tissues.

\section{Chlordecone concentration in Macrobrachium rosenbergii}

The CLD concentration was analyzed in M. rosenbergii tissues according to a method adapted from Debier et al. (2003), Guldner et al. (2010), and Multigner et al. (2010). Briefly, prawns were freeze-dried with a Benchtop 3 L Sentry Lyophilisator (VirTis, USA). The extraction of CLD was performed with a solvent mixture of $\mathrm{n}$-hexane/dichloromethane (90:10; $v / v$; Biosolve Chimie, France) using an Accelerated Solvent Extractor (ASE 200) (Dionex, Thermo Scientific, USA), and a hexanic solution of PCB congener 112 (Dr. Ehrenstorfer, Germany) was added to the samples as a surrogate internal standard. After the extraction, samples were cleaned up with $98 \%$ sulfuric acid (Merck, Germany) in order to remove organic matters (e.g., lipids, lipoproteins, carbohydrates). Then, a volume of $5 \mu \mathrm{L}$ of nonane was added in the collected phase as a keeper; samples were evaporated under a gentle nitrogen stream and resuspended in n-hexane added with a solution of PCB 209 as an injection volume internal standard (Dr. Ehrenstorfer, Germany). In parallel of the sample extractions, a procedural blank (i.e., ASE extraction without biological matrix allowing to control the extraction and the clean-up procedure) and a quality control (QC) were carried out. The QC was performed to control the CLD recovery by using a CLD-free biological matrix (here, freeze-dried Penaeus monodon) spiked with a defined concentration of CLD in order to obtain a nominal concentration of $2.5 \mathrm{ng} \mathrm{g}^{-1}$ wet weight. The purified extracts, procedural blank and QC, were analyzed by high-resolution gas chromatography. The analytical parameters were described by Guldner et al. 2010 and Multigner et al. 2010. CLD was identified based on its retention time previously determined with a linear calibration

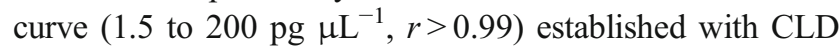
certified solutions (Riedel-de Haën, Germany). The quantification of CLD was achieved by means of the internal standard method. The CLD concentrations in each sample and in the QC were corrected with the percentage recovery of the surrogate PCB 112 and the initial sample weight. The recovery efficiency was within the limits recommended by SANCO (SANCO/12571/2013 European commission, n.d.). The limit of detection (LOD) was $0.02 \mathrm{ng} \mathrm{g}^{-1}$ wet weight and the limit of quantification (LOQ) was $0.06 \mathrm{ng} \mathrm{g}^{-1}$ wet weight. The CLD concentrations in M. rosenbergii were measured in five replicates per condition and the mean was calculated. The CLD concentrations were expressed in nanograms per gram of wet weight.

\section{0-Hydroxyecdysone concentration}

The concentrations of the 20-HE hormone and its derivatives (called "20-HE" in the following text, figures and tables) were measured by following the manufacturer's instructions of the enzyme immunoassay (EIA) kit (Cayman Chemical Company, USA), which were adapted to our biological organism (e.g., weight of tissue, solvent of homogenization, standard curve). The 20-HE concentration assessment was entirely described in Lafontaine et al. (2016).

\section{Quantification of vitellogenin and vitellogenin receptor gene relative expression levels}

\section{Total RNA extraction and cDNA synthesis}

Total RNAs were extracted from $30 \mathrm{mg}$ of tissue using the RNeasy Lipid Tissue Mini Kit (Qiagen, Germany), following the manufacturer's instructions. Quality of RNA was verified by electrophoresis on a $1.5 \%$ agarose gel in TAE buffer (Tris $40 \mathrm{mM}$, acetic acid $1 \mathrm{mM}$, EDTA $40 \mathrm{mM}$ ) and visualization under UV light, and RNA concentrations were measured using a NanoDrop ND-1000 spectrometer (NanoDrop, USA). Synthesis of complementary DNA (cDNA) was performed with $150 \mathrm{ng}$ of total RNA using the RevertAid ${ }^{\mathrm{TM}} \mathrm{H}$ Minus First Strand cDNA Synthesis Kit (Fisher Scientific) and random hexamer primers. The reverse transcription polymerase chain reaction (reverse-PCR) was performed at $42{ }^{\circ} \mathrm{C}$ for $60 \mathrm{~min}$ with a reaction mixture containing $10 \mathrm{mM}$ Tris$\mathrm{HCl}, 50 \mathrm{mM} \mathrm{KCl}, 5 \mathrm{mM} \mathrm{MgCl} 2,1 \mathrm{mM}$ dNTP mix, $2.5 \mu \mathrm{M}$ of 
random hexamer primers, $2.5 \mathrm{U} / \mu \mathrm{L}$ of RevertAid MuLV RT, and $1 \mathrm{U} / \mu \mathrm{L}$ of RiboLock RNase Inhibitor.

\section{Quantitative real-time PCR}

Evaluation of $\mathrm{Vg}$ and $\mathrm{VgR}$ gene expression levels was carried out by using quantitative real-time PCR (RT-qPCR). Specific primers were designed to amplify the corresponding cDNAs according to Roth and Khalaila (2012) and the specific gene sequences of $M$. rosenbergii available in GenBank database (Vg: accession number AB056458.1; VgR: accession number GU454802.1) (Table 2). Actin (accession number AY626840.1) (Qiu et al. 2008) and 18S (accession number KM101531.1) (Roth and Khalaila 2012) fragments were tested as housekeeping genes.

RT-qPCR was performed in 384-well plates with an ABI PRISM 7900HT system (Applied Biosystems) using MESA GREEN qPCR MasterMix (Eurogentec). A total of three technical repeats were run for each cDNA gene and primer pair (Table 2). For each reaction, an equal amount of cDNA $(4 \mu \mathrm{L}$ of the cDNAs diluted 50-fold and prepared from $150 \mathrm{ng}$ of total RNAs) was completed with a reaction mix containing $5 \mu \mathrm{L}$ of MESA GREEN qPCR MasterMix and $2.5 \mathrm{pmol}$ of each primer in a final volume of $10 \mu \mathrm{L}$. The following standard thermal profile was used: $2 \mathrm{~min}$ at $50^{\circ} \mathrm{C}, 10 \mathrm{~min}$ at $95^{\circ} \mathrm{C}$, 40 repeats of $15 \mathrm{~s}$ at $95^{\circ} \mathrm{C}$, and $60 \mathrm{~s}$ at $60^{\circ} \mathrm{C}$. At the end of the 40 repeats, dissociation curves of the amplified products were established with the following thermal steps: $15 \mathrm{~s}$ at $95^{\circ} \mathrm{C}$, $15 \mathrm{~s}$ at $60{ }^{\circ} \mathrm{C}$, and $15 \mathrm{~s}$ at $95^{\circ} \mathrm{C}$. The quality of the reactions was checked through the amplification and dissociation curves. In addition, reaction efficiencies were determined for each RT-qPCR using the LinRegPCR software v2013 (Ruijter et al. 2009). Mean reaction efficiencies were then determined for each primer pair from all reactions (>100 reactions; Table 2) and used to calculate relative gene expression levels using $18 \mathrm{~S}$ as housekeeping gene for normalization with the qBase software (Biogazelle, Hellemans et al. 2007). The 18S was selected to normalize the data, as it displayed the highest stability across the sample set (no significant differences upon a three-way ANOVA test, with $p>0.05$, taking into account "CLD exposure," "duration of exposure," and "gender" as factors).

\section{Statistical analysis}

Statistical analyses were carried out with the STATISTICA 10 Software (StatSoft 2012 USA). The data met normality and variance homogeneity which were tested with the ShapiroWilk and the Bartlett tests, respectively. First, a MANOVA test was performed in order to test the influence of gender, CLD, and duration of exposure on the whole measured parameters (Table 3). Then, to investigate the CLD bioaccumulation as well as the effects of CLD, gender, and duration of exposure on the relative expression of the $\mathrm{Vg}$ and $\mathrm{VgR}$ genes and the 20-HE concentration, data were analyzed using a three-way ANOVA test (Table 3), followed by Tukey's HSD post hoc tests which were performed to describe significant differences. A probability value of less than 0.05 was regarded as significant. The correlations between measured parameters were analyzed using the Pearson correlation coefficient.

\section{Results and discussion}

\section{Chlordecone concentration in Macrobrachium rosenbergii}

The CLD concentrations were measured in post-larvae provided by the hatchery, before the transfer in each farming pond (T0, Table 4). CLD concentrations were below the LOD, which confirmed that prawns were free of CLD contamination at the beginning of the experiment. The CLD concentrations were also measured in $M$. rosenbergii transferred in the control and the contaminated farms after 90 and 240 days of exposure (Table 4). The ANOVA results showed a significant influence of the exposure site $(p<0.05)$ on the CLD concentration in prawns. In control prawns, the very low concentrations of CLD detected could be explained by the bioaccumulation of trace amounts of CLD (lower than the LOQ in water, i.e., $0.01 \mu \mathrm{g} \mathrm{L}^{-1}$ ) detected in the river supplying the Pointe-Noire farming pond (Bonan and Prime 2001; Ministère de l'Écologie du Développement durable et de l'Énergie 2015b). The results obtained from field studies are generally more environmentally realistic and ecologically meaningful than laboratory tests (Connon et al. 2012; Crane and Babut 2007), but they are difficult to interpret, because of several confounding factors (e.g.,
Table 2 Sequences and reaction efficiencies of each primer pair for each of the studied genes

\begin{tabular}{lllll}
\hline Genes & Species & Primers & Efficiency \\
\cline { 3 - 4 } & & Forward 5-3 & Reverse 5-3 & \\
\hline$V g$ & M. rosenbergii & $\begin{array}{c}\text { GCGAAAAGGTAAAG } \\
\text { CACGGAGT }\end{array}$ & $\begin{array}{c}\text { ACGGCGCAAGAAAT } \\
\text { GTAATGC }\end{array}$ & $1.957 \pm 0.083$ \\
$V g R$ & $M$. rosenbergii & CTCCCTTGACTACG & $\begin{array}{c}\text { GCATTGCATCTTGA } \\
\text { GCTGCAAC }\end{array}$ & $1.911 \pm 0.068$ \\
$18 S$ & $M$. rosenbergii & $\begin{array}{c}\text { TAGCAATTCGCCGT } \\
\text { CGTTATTC }\end{array}$ & $\begin{array}{c}\text { CTACCCCCGGAACT } \\
\text { CAAAGACT }\end{array}$ & $2.127 \pm 0.141$ \\
\hline
\end{tabular}


Table 3 Univariate and multivariate analyses of variance (ANOVA/MANOVA) investigating variations in vitellogenin $(\mathrm{Vg})$ and vitellogenin receptor $(\mathrm{VgR})$ gene expressions and 20-HE concentrations according to chlordecone exposure (CLD), gender, and duration of exposure

\begin{tabular}{|c|c|c|c|}
\hline $\begin{array}{l}\text { MANOVA } \\
\text { Sources of variation }\end{array}$ & \multicolumn{3}{|l|}{$p$ values } \\
\hline Gender & $<0.0001$ & & \\
\hline CLD & $<0.0001$ & & \\
\hline Duration of exposure & 0.06 & & \\
\hline Gender $\times$ CLD & 0.04 & & \\
\hline Gender $\times$ duration of exposure & 0.002 & & \\
\hline $\mathrm{CLD} \times$ duration of exposure & 0.01 & & \\
\hline Gender $\times$ CLD $\times$ duration of exposure & 0.03 & & \\
\hline ANOVA & $p$ values & & \\
\hline Sources of variation & Vg gene & VgR gene & 20-HE level \\
\hline Gender & $<0.0001$ & $<0.0001$ & 0.07 \\
\hline CLD & 0.36 & 0.002 & $<0.0001$ \\
\hline Duration of exposure & 0.70 & 0.33 & 0.009 \\
\hline Gender $\times$ CLD & 0.64 & 0.003 & 0.75 \\
\hline Gender $\times$ duration of exposure & 0.41 & 0.51 & $<0.0001$ \\
\hline CLD $\times$ duration of exposure & 0.025 & 0.06 & 0.68 \\
\hline Gender $\times$ CLD $\times$ duration of exposure & 0.011 & 0.03 & 0.02 \\
\hline
\end{tabular}

season, other chemicals). However, the CLD accumulation observed here is consistent with the fact that CLD has a high potential of bioaccumulation in aquatic organisms, based on its physicochemical properties, even when concentrations are very low (ATSDR et al. 1995). As expected, a significant accumulation of CLD was observed in prawns sampled in the contaminated pond (Saint-Claude). This result is in agreement and of the same order than those of Monti (2007) who measured CLD concentrations of $2204 \mathrm{ng} \mathrm{g}^{-1}$ in $M$. carcinus and $1134 \mathrm{ng} \mathrm{g}^{-1}$ in M. faustinum, sampled in the Rivière aux Herbes, which is the river supplying the Saint-Claude pond, used as contaminated site in the present study. On the contrary, the CLD concentrations measured in $M$. rosenbergii in the present study were higher than those measured in the same organism in another in situ study (Gaume et al. 2014). This difference is probably due to the duration of exposure, since Gaume et al. (2014) studied a 96-h exposure compared to our study where prawns were exposed for 90 and 240 days. Nevertheless, results of these studies show clearly that the CLD is constantly accumulated in M. rosenbergii, especially after a long-term exposure.

\section{0-Hydroxyecdysone concentration}

The results revealed that 20 -HE concentration was significantly influenced by the CLD exposure. Indeed, it was observed that 20-HE concentrations were from 1.3-fold to 1.9-fold lower in prawns exposed in the contaminated site compared to the control prawns, whatever the duration of exposure (Fig. 1). This decrease was significant in female $M$. rosenbergii exposed for 90 days and in males and females exposed for 240 days. Moreover, a significantly negative correlation between 20-HE concentrations and CLD concentrations measured in prawns was obtained ( $p=0.0019, r=-0.70)$. A decrease of the 20-HE hormone in $M$. rosenbergii has already been observed in the presence of CLD in our previous study in laboratory conditions (Lafontaine et al. 2016). The same result obtained here supports the hypothesis that CLD could be an endocrine disruptor in invertebrates.

Chlordecone can be considered a steroid receptor ligand (Kavlock 1996), and various EDCs have been shown to act
Table 4 CLD bioconcentrations (mean \pm S.D.), on a wet weight basis, measured in

Macrobrachium rosenbergii sampled in the control (Pointe-

Noire) and the contaminated site (Saint-Claude), as well as postlarvae, before the transfer in each farming pond (T0)

\begin{tabular}{llll}
\hline CLD concentration in prawns $\left(\mathrm{ng} \mathrm{g}^{-1}\right)$ & & Pointe-Noire & Saint-Claude \\
\hline T0 & & $<$ LOD & $<$ LOD \\
\hline \multirow{2}{*}{90 days } & Males & $9.09 \pm 9.20$ & $858.50 \pm 92.09^{\mathrm{a}}$ \\
& Females & $13.01 \pm 3.79$ & $646.51 \pm 58.40^{\mathrm{a}}$ \\
& Males & $13.57 \pm 4.04$ & $767.03 \pm 144.64^{\mathrm{a}}$ \\
& Females & $9.04 \pm 3.69$ & $1247.39 \pm 238.22^{\mathrm{a}}$ \\
\hline
\end{tabular}

${ }^{a}$ Significantly different values of CLD concentrations between control and contaminated samples. LOD limit of detection 
Fig. 1 20-HE concentrations $\left(\mathrm{pg} \mathrm{g}^{-1}\right.$; mean \pm S.D.) in hepatopancreas of male and female Macrobrachium rosenbergii, sampled after 90 and 240 days of exposure in control and chlordecone-contaminated sites. Different letters above the bars indicate significant differences for each duration of exposure (Tukey's HSD test, $p$ values $<0.05$ )

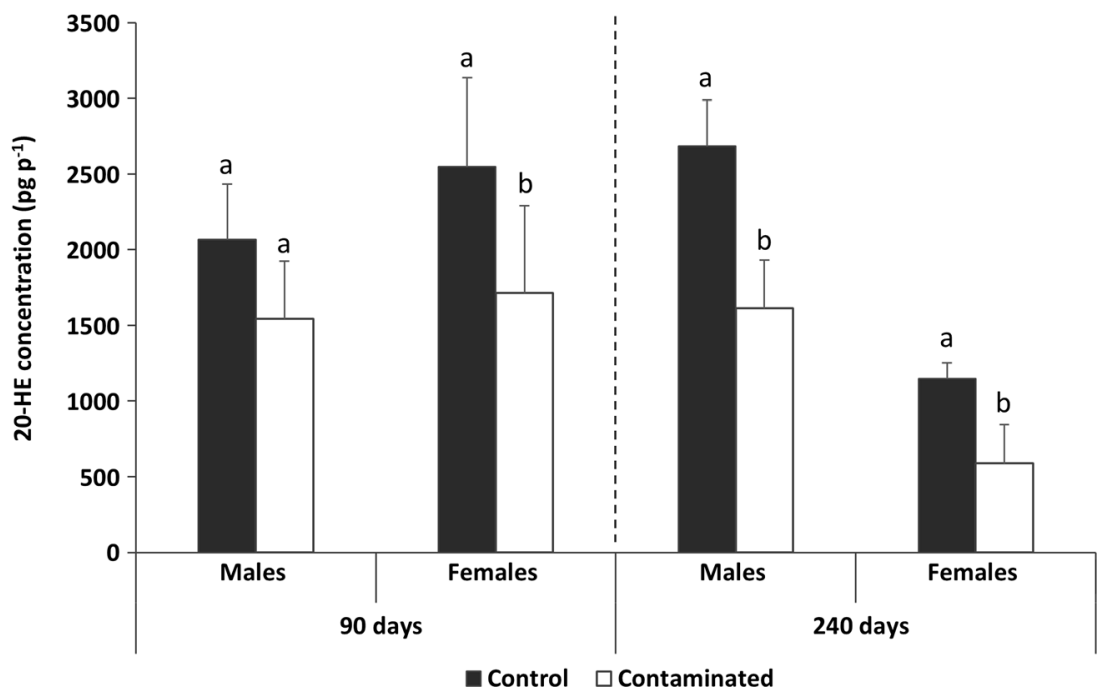

as ecdysteroid synthesis inhibitors or ecdysteroid receptors (EcR) antagonists in crustaceans (LeBlanc 2007), leading to a possible decrease of ecdysteroid concentrations (ForgetLeray et al. 2005; Rodriguez et al. 2007). Consequently, CLD could be responsible for the decrease in the 20-HE concentration by binding directly to EcR, as a consequence of a potential anti-ecdysteroidal activity (Zou and Fingerman 1999; Zou 2005). The secretion of 20-HE by the crustacean Y-organ is under negative control of the molt-inhibiting hormone (MIH), which is a hormone secreted by the X-organ/ sinus gland complex (Rodriguez et al. 2007). The 20-HE hormone might have a feedback control on the production and/or release of MIH from the X-organ/sinus gland complex located in the eyestalk or on the ecdysteroid synthesis in Y-organs (Dell et al. 1999; Techa and Chung 2015). The presence of EcRs in eyestalks and Y-organs of decapod species has been demonstrated and supports these suggestions (Chang and Mykles 2011; Chung et al. 1998; Dell et al. 1999; Techa and Chung 2013). The binding of CLD on EcR in the X- or Yorgan could thus disrupt the 20-HE synthesis. However, as in other EDCs, CLD may interfere with the endocrine system by several mechanisms, at any step of the transduction pathway of the hormones (Hyne 2011; Rodriguez et al. 2007). Methyl farnesoate (MF), the secretion of which is inhibited by the mandibular organ-inhibiting hormone (MOIH) from the Xorgan, stimulates the secretion of 20-HE (Rodriguez et al. 2007). The decrease of 20-HE concentration observed in exposed prawns could also be due to the disruption of the mandibular organ (through $\mathrm{MOIH}$ ) following an interaction of CLD with the X-organ. These effects of CLD on the 20-HE concentration could therefore affect the organism growth and development in the long term but also the reproduction of prawns since the 20-HE is involved in the reproduction process (Hyne 2011; LeBlanc et al. 2000; Rodriguez et al. 2007; Snyder and Mulder 2001).

\section{Expression of the vitellogenin gene}

The results revealed that the expression of the $\mathrm{Vg}$ gene was significantly influenced by gender of prawns, as well as the interaction between gender, CLD concentration, and duration of exposure and the interaction between CLD concentration and duration of exposure (Table 3). The results showed that the expression of the $\mathrm{Vg}$ gene was not completely silent in males and that strong differences in $\mathrm{Vg}$ gene expression were observed between males and females $(p<0.0001)$. These results confirm the baseline level of $\mathrm{Vg}$ in male crustaceans as reported in the copepod Tigriopus japonicus (Lee et al. 2008) or in the amphipod Gammarus fossarum (Jubeaux et al. 2012). Moreover, no significant difference $(p>0.05)$ was detected between the Vg gene expression measured in CLD-exposed and control males after 90 days of exposure, although a trend of increase was observed after 240 days of exposure (Fig. 2a). Conversely, in females, a trend of decrease was observed after 90 days of exposure, while a significant increase $(p=0.04)$ of $\mathrm{Vg}$ gene expression was measured after 240 days of exposure, compared to respective controls (Fig. 2b). In addition, a significantly positive correlation $(p=0.01, r=0.70)$ between $\mathrm{Vg}$ gene expression and the CLD concentrations measured in prawns was obtained, suggesting that a relationship exists between the CLD exposure and the modification of $\mathrm{Vg}$ gene expression in $M$. rosenbergii.

The increase of the Vg gene expression after a CLD exposure has been observed in some vertebrates, through the interaction with the estrogen receptor (Donohoe and Curtis 1996; Flouriot et al. 1996; Hammond et al. 1979). For example, an increase of the $\mathrm{Vg}$ synthesis in the juvenile trout Oncorhynchus mykiss fed during 33 weeks with CLD-contaminated food $\left(0.4 \mathrm{mg} \mathrm{kg}^{-1} \mathrm{day}^{-1}\right.$ ) was measured (Donohoe and Curtis 1996). However, Thornton et al. (2003) assumed the loss of the estrogen receptor in ecdysozoans, which invalidates the 

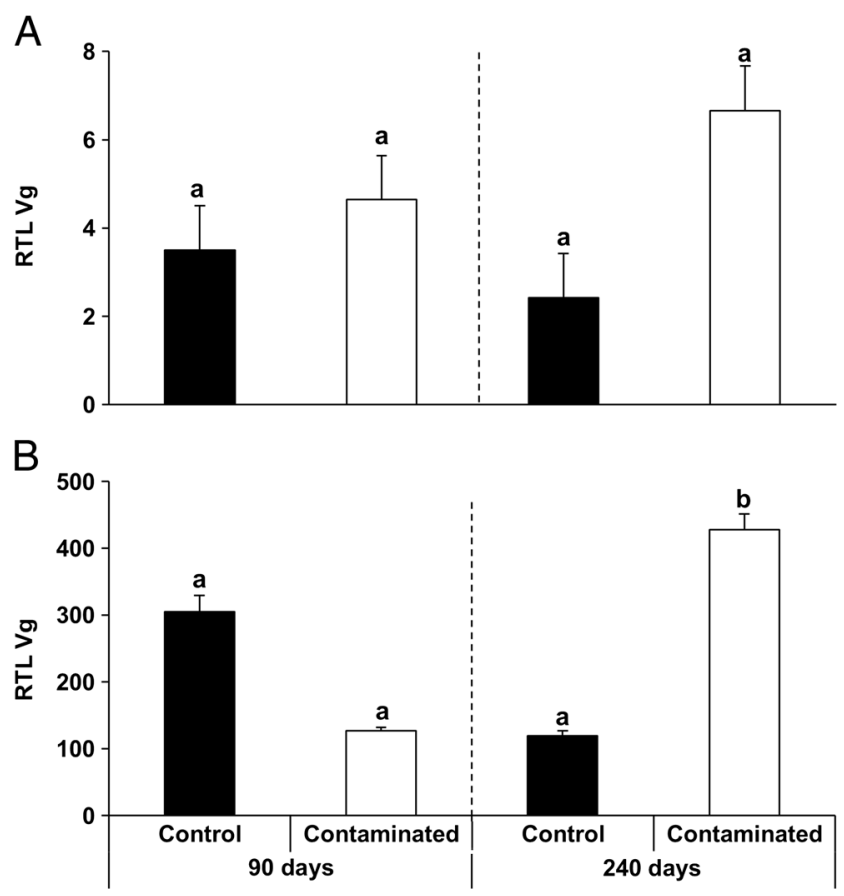

Fig. 2 Relative transcript levels (RTL) of the Vg gene in hepatopancreas of male (a) and female (b) Macrobrachium rosenbergii, sampled after 90 and 240 days of exposure in control and chlordecone-contaminated sites. Expression levels are relative to rRNA $18 \mathrm{~S}$ and are the average of 10 replicates (means $\pm \mathrm{SE}$ ). Different letters above the bars indicate significant differences for each duration of exposure (Tukey's HSD test, $p$ values $<0.05$ )

hypothesis of an interaction between CLD and an estrogen receptor in $M$. rosenbergii. Nevertheless, previous investigations showed an increase of the $\mathrm{Vg}$ gene expression in crustaceans exposed to EDCs (e.g., xenoestrogen compounds) (Billinghurst et al. 2000; Ghekiere et al. 2006; Huang and Chen 2004; Huang et al. 2006; Oberdörster et al. 2000; Sanders et al. 2005). For example, in female shrimp Neocaridina denticulata, $\mathrm{Vg}$ gene expression was induced by exposure to chlordane at 0.001 and $0.01 \mu \mathrm{g} \mathrm{L}^{-1}$ (Huang et al. 2006), suggesting that chlordane may cause some reproductive impairments and alterations in endocrine functions.

As biological functions in crustaceans are hormonally dependent (Hyne 2011), our results could be explained by an interaction of the CLD with the endocrine system of M. rosenbergii. Shrivastava and Princy (2014) indicated that MIH inhibits the 20-HE synthesis in the Y-organ on the one hand and stimulates vitellogenesis in the hepatopancreas on the other hand. As all of the chemical insecticides, CLD is not species-selective with regard to targets of toxicity and it has neurotoxic properties since it interferes with the nervous system of the target organisms (Costa 2015). Therefore, CLD could affect the secretion of neurohormones in crustaceans by binding with key receptors such as steroid receptor (Kavlock 1996), or EcR, but no information is available regarding the potential interaction between CLD and EcR. However, CLD could interact with the X-organ of
M. rosenbergii, through EcR, causing an increase of the synthesis and/or release of MIH, which would explain the decrease of the 20-HE concentration coupled with an increase of the $\mathrm{Vg}$ gene expression, observed here.

CLD exposure could also inhibit the gonad-inhibiting hormone (GIH) synthesis, resulting in an increase of the vitellogenin production. Another hypothesis could be that the increase of $\mathrm{Vg}$ expression would be due to an increase of the gonad-stimulating hormone (GSH) from the thoracic ganglion or the vitellogenin-stimulating ovarian hormone (VSOH) from the ovary, which seem to play a similar role as $17 \beta-$ estradiol in egg-laying vertebrates (Hasegawa et al. 1993; Kusk and Wollenberger 2007). Finally, the last assumption is related to the low levels of 20-hydroxyecdyone (as observed here after CLD exposure) coupled with the secretion of GSH by the thoracic ganglion, which could initiate the production of vitellogenin (Hyne 2011). This assumption is supported by a negative, but not significant correlation between 20-HE concentration and Vg expression. The 20-HE/Vg relationship was previously investigated by Young et al. (1993) in P. monodon, who observed low 20-HE concentration when high Vg concentrations were measured.

\section{Expression of vitellogenin receptor gene}

The results revealed that the expression of the VgR gene was significantly influenced by gender and CLD exposure, as well as by the interaction between these two factors (Table 3). Moreover, the level of expression of the VgR gene was impacted by the interaction between gender, CLD exposure, and duration of exposure. In males (Fig. 3a) and females (Fig. 3b), the level of $\mathrm{VgR}$ expression was significantly increased in exposed prawns compared to respective controls, whatever the duration of exposure. These observations suggested that a relationship exists between the CLD exposure and the modification of $\mathrm{VgR}$ gene expression in both $M$. rosenbergii genders. Indeed, a strong significant positive correlation between $\mathrm{VgR}$ gene expression and the CLD concentrations in prawns was also observed ( $p=0.04, r=0.64)$ and supports this relationship. Moreover, the results obtained in males showed that, in addition to the $\mathrm{Vg}$ gene, male $M$. rosenbergii expressed also the gene of the vitellogenin receptor.

$\mathrm{VgR}$ is a receptor on the oocyte membrane having a high affinity for the $\mathrm{Vg}$ proteins and which mediates the endocytic process required for the internalization of $\mathrm{Vg}$ in oocytes by a receptor-mediated endocytosis (Raikhel and Dhadialla 1992; Sappington and Raikhel 1998; Tiu et al. 2008). The presence of this Vg-specific receptor on the oocyte membrane has been shown in invertebrates such as insect species (Raikhel and Dhadialla 1992; Sappington and Raikhel 1998) or shrimps Penaeus monodon (Tiu et al. 2008) and M. rosenbergii used in this study (Roth and Khalaila 2012). However, although VgR plays an important role in oocyte maturation through 


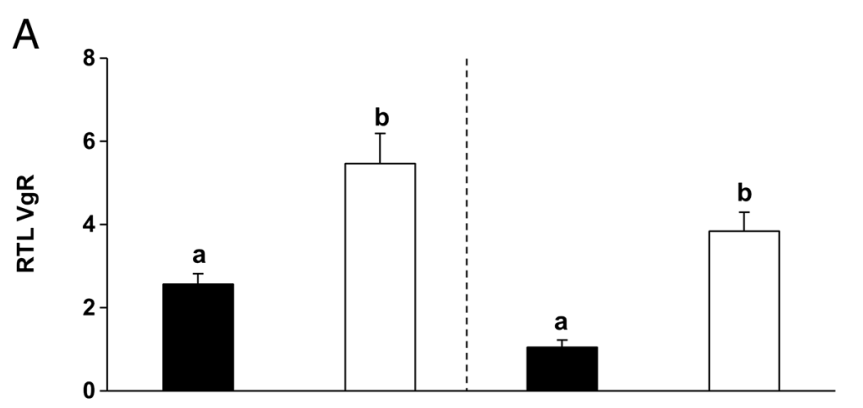

B

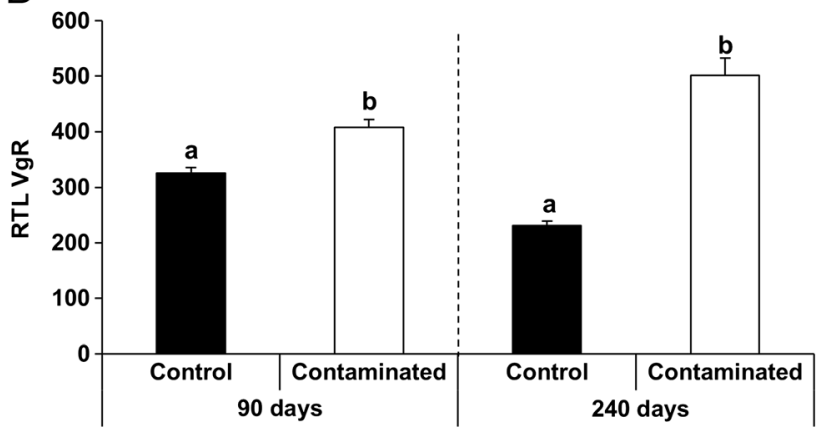

Fig. 3 Relative transcript levels (RTL) of the VgR gene in gonads of male (a) and female (b) Macrobrachium rosenbergii sampled after 90 and 240 days in control and chlordecone-contaminated sites. Expression levels are relative to rRNA $18 \mathrm{~S}$ and are the average of 10 replicates (means $\pm \mathrm{SE}$ ). Different letters above the bars indicate significant differences for each duration of exposure (Tukey's HSD test, $p$ values $<0.05)$

the Vg incorporation in the gonadal tissue (Tiu et al. 2008), only a few studies focused on $\mathrm{VgR}$ gene expression or $\mathrm{VgR}$ levels in crustaceans (Subramoniam 2011). Moreover, to our knowledge, no study has considered the modification of $\mathrm{VgR}$ gene expression in the presence of EDCs.

In the present study, CLD significantly increased the expression of the VgR gene in both genders, whatever the duration of exposure. So far, it is difficult to compare our results to previous studies because none dealt with the effects of EDCs on this receptor. However, the induction of $\mathrm{VgR}$ expression could be explained by the increase of the Vg expression as suggested by Tiu et al. (2008) in the shrimp P. monodon. In their study, the authors supposed that the VgR could be overexpressed in order to provide more receptors for increased amounts of $\mathrm{Vg}$. This assumption is supported by a significant positive correlation ( $p=0.003, r=0.88$ ) between $\mathrm{Vg}$ and $\mathrm{VgR}$ expressions. Otherwise, the induction of the $\mathrm{VgR}$ expression could be due to an effect of CLD similar to that of the MIH. As suggested above, CLD could be an agonist of $\mathrm{MIH}$, resulting in both a decrease of 20-HE and an increase of Vg. The interaction between CLD and the X-organ could also inhibit the $\mathrm{GIH}$ synthesis, resulting in an increase of both $\mathrm{Vg}$ and $\mathrm{VgR}$. In the same way, this increase of $\mathrm{VgR}$ expression could be the consequence of the synthesis of GSH by a direct action of CLD on the thoracic ganglion or indirectly for example through a disturbance of the serotonin. Indeed, in crustaceans, serotonin is identified as a neurotransmitter that stimulates release of some neurohormones such as crustacean hyperglycemic hormone $(\mathrm{CHH})$ or MIH (Keller and Beyer 1968; Mattson and Spaziani 1985) and inhibits the release of GIH (Kulkarni and Glade 1991; Tinikul et al. 2008). Processes regulated by serotonin may become a target for environmentally relevant endocrine disruptors, such as insecticides because of their neurotoxic properties (Brooks et al. 2003; Henry et al. 2004; Mazurová et al. 2008). The assumption on the serotonin involvement in the $\mathrm{Vg}$ and $\mathrm{VgR}$ gene expressions is supported by the fact that Ruttanakorn et al. (2014) observed an increase of the Vg concentration in M. rosenbergii, after serotonin injection.

Our results suggest that CLD could act on endocrine pathways involved in the reproduction and molt processes. It could act through the X-organ, which is one of the main neuroendocrine organs in crustaceans, or through the Y-organ or thoracic ganglion, or several endocrine structures simultaneously.

The incorporation of $\mathrm{Vg}$ by $\mathrm{VgR}$ into the oocytes is essential to the reproduction process of the organism (e.g., survival and development of eggs) (Roth and Khalaila 2012). Although it was already observed in vertebrates that changes in $\mathrm{Vg}$ expression could cause disruptions of reproduction and population dynamics in the long term (Bosker et al. 2010; Kidd et al. 2007; MartínDíaz et al. 2005), in invertebrates, this question is less advanced. However, it was observed in several crustacean species that a modification of the $\mathrm{Vg}$ gene expression causes reproduction impairments as well as growth disturbances (Hannas et al. 2011; Tokishita et al. 2006). Moreover, impairments in reproduction (i.e., infertility of females) have been related to a deficiency of VgR in Drosophila melanogaster females (Schonbaum et al. 1995). According to these previous studies and our results, it appears that CLD could disrupt the reproduction and/or development of the decapod crustacean $M$. rosenbergii through the modification of the molting hormone (20-HE) and $\mathrm{Vg}$ and $\mathrm{VgR}$ gene expression. However, due to the fact that this study was carried out in field conditions, confounding factors should be considered in further studies to incriminate the observed effects only to the CLD exposure.

\section{Conclusion}

The present study is the first to link the CLD effects on the 20-HE concentration and both $\mathrm{Vg}$ and $\mathrm{VgR}$ gene expressions in crustaceans. The results revealed that the expression of $\mathrm{Vg}$ and $\mathrm{VgR}$ genes in $M$. rosenbergii were modified following a CLD exposure and that CLD decreased the 20-HE concentration as previously observed in the laboratory experiment. Since Vg, VgR, and 20-HE are hormonally controlled, these observations suggest a potential disruption of the endocrine system of crustaceans after a CLD exposure. Consequently, CLD seems to be an EDC for M. rosenbergii and more generally for crustaceans. However, this 
study only revealed a possible relation of putatively endocrinedisrupting effects of CLD in an environmentally relevant context, but did not focus on the underlying mechanisms. Further investigations are thus needed to explain how CLD acts on hormonal control and/or metabolic pathways, especially by focusing on the $\mathrm{X} / \mathrm{Y}$-organs, their receptors (e.g., ecdysteroid receptor), and their secreted hormones (e.g., MIH, GIH).

Acknowledgments The present study was financially supported by grants from the National Research Agency (MACHLOMA, ANR-10CESA-014, France) and by Belgium funds under a FNRS-F.R.I.A. grant (Fonds pour la Formation à la Recherche dans l'Industrie et dans l'Agriculture). The authors thank Patrick Boucher and François Herman (OCEAN-SA), Nathalie Dodet (LEAE) and Fanny Caupos (INRA) for their help in the establishment of the experiment, and Catherine Adam (LEAE) for her technical assistance.

\section{References}

Anon. (2008) Arrêté du 30 juin 2008 relatif aux limites maximales applicables aux résidus de chlordécone que ne doivent pas dépasser certaines denrées alimentaires d'origine végétale et animale pour être reconnues propres à la consommation humaine. JORF 4 juillet 2008.

Arukwe A, Goksøyr A (2003) Eggshell and egg yolk proteins in fish: hepatic proteins for the next generation: oogenetic, population, and evolutionary implications of endocrine disruption. Comp Hepatol 2: 4. doi:10.1186/1476-5926-2-4

ATSDR, Faroon O, Kueberuwa S, Smith L, Derosa C, U.S. Department of Health and Human Services, P.H.S. (1995) Toxicological profile for mirex and chlordecone. Toxicol Ind Heal 11:1-195. doi:10.1177 /074823379501100601

Billinghurst Z, Clare AS, Matsumura K, Depledge MH (2000) Induction of cypris major protein in barnacle larvae by exposure to 4-nnonylphenol and 17ß-oestradiol. Aquat Toxicol 47:203-212. doi:10.1016/S0166-445X(99)00018-1

Bonan H, Prime J-L (2001) Rapport sur la présence de pesticides dans les eaux de consommation humaine en Guadeloupe. Ministère l'aménagement du Territ. l'environnement pp.86.

Bosker T, Munkittrick KR, Maclatchy DL (2010) Challenges and opportunities with the use of biomarkers to predict reproductive impairment in fishes exposed to endocrine disrupting substances. Aquat Toxicol 100:9-16. doi:10.1016/j.aquatox.2010.07.003

Brooks BW, Turner PK, Stanley JK, Weston JJ, Glidewell EA, Foran CM, Slattery M, La Point TW, Huggett DB (2003) Waterborne and sediment toxicity of fluoxetine to select organisms. Chemosphere 52:135-142. doi:10.1016/S0045-6535(03)00103-6

Cabidoche YM, Lesueur-Jannoyer M (2012) Contamination of harvested organs in root crops grown on chlordecone-polluted soils. Pedosphere 22:562-571. doi:10.1016/S1002-0160(12)60041-1

Cavelier N (1980) Contamination de la Faune par les pesticides organochlorés. In: Kermarrec A (ed) Niveau actuel de la contamination des chaînes biologiques en Guadeloupe : pesticides et métaux lourds. INRA, contrat $n^{\circ}$ 7883. ministère de l'Environnement et du Cadr, Paris

Chang ES, Mykles DL (2011) Regulation of crustacean molting: a review and our perspectives. Gen Comp Endocrinol 172:323-330. doi:10.1016/j.ygcen.2011.04.003

Chung AC-K, Durica DS, Hopkins PM (1998) Tissue-specific patterns and steady-state concentrations of ecdysteroid receptor and retinoidX-receptor mRNA during the molt cycle of the fiddler crab, Uca pugilator. Gen Comp Endocrinol 109:375-389. doi:10.1006 /gcen.1997.7046
Connon RE, Geist J, Werner I (2012) Effect-based tools for monitoring and predicting the ecotoxicological effects of chemicals in the aquatic Environment. Sensors 12:12741-12771. doi:10.3390/s120912741

Costa LG (2015) Chapter 9 - The neurotoxicity of organochlorine and pyrethroid pesticides. In: Handbook of Clinical Neurology. p 135148. doi:10.1016/B978-0-444-62627-1.00009-3

Crane M, Babut M (2007) Environmental quality standards for water framework directive priority substances: challenges and opportunities. Integr Environ Assess Manag 3:290. doi:10.1897/IEAM_2006-045.1

Curtis LR, Beyers RJ (1978) Inhibition of oviposition in the teleost oryzias latipes, induced by subacute kepone exposure. Comp Biochem Physiol Part C Comp Pharmacol 61:15-16. doi:10.1016 /0306-4492(78)90103-X

Debier C, Pomeroy PP, Dupont C, Joiris C, Comblin V, Le Boulengé E, Larondelle Y, Thomé JP (2003) Quantitative dynamics of PCB transfer from mother to pup during lactation in UK grey seals Halichoerus grypus. Mar Ecol Prog Ser 247:237-248. doi:10.3354 /meps 247249

Dell S, Sedlmeier D, Bocking D, Dauphin-Villemant C (1999) Ecdysteroid biosynthesis in crayfish Y-organs: feedback regulation by circulating ecdysteroids. Arch Insect Biochem Physiol 41:148 155. doi:10.1002/(SICI)1520-6327(1999)41:3<148::AID-ARCH6 $>3.0 . \mathrm{CO} ; 2-\mathrm{U}$

DIREN Guadeloupe (2003) Cartographie de la contamination par les pesticides des eaux superficielles de Guadeloupe - Direction régionale de l'Environnement - Observatoire des résidus phytosanitaires [WWW Document]., URL., http://www.observatoire-pesticides.gouv. fr/upload/bibliotheque/299193573082030758981064849186 /guadeloupe-qualite-cours-eau-2003.gif

Donohoe RM, Curtis LR (1996) Estrogenic activity of chlordecone, o, p'DDT and o, p'-DDE in juvenile rainbow trout: induction of vitellogenesis and interaction with hepatic estrogen binding sites. Aquat Toxicol 36:31-52. doi:10.1016/S0166-445X(96)00799-0

Flouriot G, Pakdel F, Valotaire Y (1996) Transcriptional and posttranscriptional regulation of rainbow trout estrogen receptor and vitellogenin gene expression. Mol Cell Endocrinol 124:173-183. doi:10.1016/S0303-7207(96)03960-3

Forget-Leray J, Landriau I, Minier C, Leboulenger F (2005) Impact of endocrine toxicants on survival, development, and reproduction of the estuarine copepod Eurytemora affinis (Poppe). Ecotoxicol Environ Saf 60:288-294. doi:10.1016/j.ecoenv.2004.06.008

Gaume B, Dodet N, Thomé JP, Lemoine S (2014) Expression of biotransformation and oxidative stress genes in the giant freshwater prawn Macrobrachium rosenbergii exposed to chlordecone. Environ Sci Pollut Res. doi:10.1007/s11356-014-3134-y

Ghekiere A, Verslycke T, Janssen C (2006) Effects of methoprene, nonylphenol, and estrone on the vitellogenesis of the mysid Neomysis integer. Gen Comp Endocrinol 147:190-5. doi:10.1016 /j.ygcen.2005.12.021

Gismondi E, Thomé JP (2014) Effects of two PBDE congeners on the moulting enzymes of the freshwater amphipod Gammarus pulex. Environ Pollut 191:119-125. doi:10.1016/j.envpol.2014.04.017

Giusti A, Lagadic L, Barsi A, Thomé JP, Joaquim-Justo C, Ducrot V (2014) Investigating apical adverse effects of four endocrine active substances in the freshwater gastropod Lymnaea stagnalis. Sci Total Environ 493:147-155. doi:10.1016/j.scitotenv.2014.05.130

Guldner L, Multigner L, Héraud F, Monfort C, Pierre Thomé J, Giusti A, Kadhel P, Cordier S (2010) Pesticide exposure of pregnant women in Guadeloupe: ability of a food frequency questionnaire to estimate blood concentration of chlordecone. Environ Res 110:146-151. doi:10.1016/j.envres.2009.10.015

Guzelian PS (1982) Comparative toxicology of chlordecone (Kepone) in humans and experimental animals. Annu Rev Pharmacol Toxicol 22:89-113. doi:10.1146/annurev.pa.22.040182.000513

Hammond B, Katzenellenbogen BS, Krauthammer N, McConnell J (1979) Estrogenic activity of the insecticide chlordecone (Kepone) 
and interaction with uterine estrogen receptors. Proc Natl Acad Sci U S A 76:6641-6645. doi:10.1073/pnas.76.12.6641

Hannas BR, Wang YH, Thomson S, Kwon G, Li H, Leblanc GA (2011) Regulation and dysregulation of vitellogenin mRNA accumulation in daphnids (Daphnia magna). Aquat Toxicol 101:351-7. doi:10.1016/j.aquatox.2010.11.006

Hasegawa Y, Hirose E, Katakura Y (1993) Hormonal control of sexual differentiation and reproduction in Crustacea. Am Zool 33:403-411. doi:10.1093/icb/33.3.403

Hellemans J, Mortier G, De Paepe A, Speleman F, Vandesompele J (2007) qBase relative quantification framework and software for management and automated analysis of real-time quantitative PCR data. Genome Biol 8:R19. doi:10.1186/gb-2007-8-2-r19

Henry TB, Kwon J-W, Armbrust KL, Black MC (2004) Acute and chronic toxicity of five selective serotonin reuptake inhibitors in Ceriodaphnia dubia. Environ Toxicol Chem 23:2229-2233. doi:10.1897/03-278

Huang D-J, Chen H-C (2004) Effects of chlordane and lindane on testosterone and vitellogenin levels in green neon shrimp (Neocaridina denticulata). Int J Toxicol 23:91-5. doi:10.1080/10915810490435604

Huang DJ, Chen HC, Wu JP, Wang SY (2006) Reproduction obstacles for the female green neon shrimp (Neocaridina denticulata) after exposure to chlordane and lindane. Chemosphere 64:11-16. doi:10.1016 /j.chemosphere.2005.12.017

Hyne RV (2011) Review of the reproductive biology of amphipods and their endocrine regulation: identification of mechanistic pathways for reproductive toxicants. Environ Toxicol Chem 30:2647-2657. doi:10.1002/etc. 673

Jones PD, Tremblay LA, De Coen WM, Glesy JP (2000) Vitellogenin as a biomarker for environmental estrogens. Aust J Ecotoxicol 6:45-58

Jubeaux G, Simon R, Salvador A, Quéau H, Chaumot A, Geffard O (2012) Vitellogenin-like proteins in the freshwater amphipod Gammarus fossarum (Koch, 1835): functional characterization throughout reproductive process, potential for use as an indicator of oocyte quality and endocrine disruption biomarker in males. Aquat Toxicol 112-113:72-82. doi:10.1016/j.aquatox.2012.01.011

Kavlock RJ (1996) Pesticides as endocrine-disrupting chemicals, in: Handbook of pesticide toxicology. U.S. Environmental Protection Agency, Washington DC

Keller R, Beyer J (1968) Zur hyperglykämischen Wirkung von Serotonin und Augenstielextrakt beim Flusskrebs Orconectes limosus. Z Vgl Physiol 59:78-85

Kidd KA, Blanchfield PJ, Mills KH, Palace VP, Evans RE, Lazorchak JM, Flick RW (2007) Collapse of a fish population after exposure to a synthetic estrogen. Proc Natl Acad Sci 104:8897-8901. doi:10.1073/pnas.0609568104

Kortenkamp A, Martin O, Faust M, Evans R, Mckinlay R, Orton F, Rosivatz E (2011) State of the art assessment of endocrine disrupters. European Commission, Brussels

Kulkarni G, Glade L (1991) Oogenesis and effects of neuroendocrine tissues on in vitro synthesis of protein by the ovary of the red swamp crayfish Procambarus clarkii (Girard). J Crustac Biol 11(4):513-522

Kusk KO, Wollenberger L (2007) Towards an internationally harmonized test method for reproductive and developmental effects of endocrine disrupters in marine copepods. Ecotoxicology 16:183-195. doi:10.1007/s10646-006-0112-2

Lafontaine A, Gismondi E, Boulangé-Lecomte C, Geraudie P, Dodet N, Caupos F, Lemoine S, Lagadic L, Thomé J-P, Forget-Leray J (2016) Effects of chlordecone on 20-hydroxyecdysone concentration and chitobiase activity in a decapod crustacean, Macrobrachium rosenbergii. Aquat Toxicol 176:53-63. doi:10.1016/j. aquatox.2016.04.006

LeBlanc G a, Mu X, Rider CV (2000) Embryotoxicity of the alkylphenol degradation product 4-nonylphenol to the crustacean Daphnia magna. Environ Health Perspect 108:1133-1138. doi:10.1289 /ehp.001081133
LeBlanc GA (2007) Crustacean endocrine toxicology: a review. Ecotoxicology 16:61-81. doi:10.1007/s10646-006-0115-Z

Lee K-W, Hwang D-S, Rhee J-S, Ki J-S, Park HG, Ryu J-C, Raisuddin S, Lee J-S (2008) Molecular cloning, phylogenetic analysis and developmental expression of a vitellogenin (Vg) gene from the intertidal copepod Tigriopus japonicus. Comp Biochem Physiol B Biochem Mol Biol 150:395-402. doi:10.1016/j.cbpb.2008.04.009

Martín-Díaz ML, Villena-Lincoln A, Bamber S, Blasco J, DelValls TA (2005) An integrated approach using bioaccumulation and biomarker measurements in female shore crab, Carcinus maenas. Chemosphere 58:615-26. doi:10.1016/j.chemosphere.2004.08.072

Mattson MP, Spaziani E (1985) Characterization of molt-inhibiting hormone (MIH) action on crustacean Y-organ segments and dispersed cells in culture and a bioassay for MIH activity. J Exp Zool 236:93101. doi:10.1002/jez. 1402360113

Mazurová E, Hilscherová K, Triebskorn R, Köhler H-R, Maršálek B, Bláha L (2008) Endocrine regulation of the reproduction in crustaceans: Identification of potential targets for toxicants and environmental contaminants. Biologia. 63:139-150. doi:10.2478/s11756-008-0027-x

Ministère de l'Écologie du Développement durable et de l'Énergie, (2015a). JORF n ${ }^{\circ} 0198$ 28/08/2015 - DEVL1513989A - Arrêté du 27 juillet 2015 modifiant l'arrêté du 25 janvier 2010 relatif aux méthodes et critères d'évaluation de l'état écologique, de l'état chimique et du potentiel écologique des eaux de surface pris en appl.

Ministère de l'Écologie du Développement durable et de l'Énergie (2015a) JORF n॰0260 08/11/2015 - DEVL1525745V - Avis relatif aux limites de quantification des couples « paramètre-matrice » de l'agrément des laboratoires effectuant des analyses dans le domaine de l'eau et des milieux aquatiques. Journal Officiel De La République, FRANÇAISE

Monti D (2007) Evaluation de la biocontamination en Chlordecone, $\beta$ Hexachlorocyclohexane et Cadusaphos de Crustacés et Poissons d'eau douce en Guadeloupe, Ministère de l'Ecologie, du Développement et de l'Aménagement durables. Ministère de l'Ecologie, du Développement et de l'Aménagement durables

Multigner L, Ndong JR, Giusti A, Romana M, Delacroix-Maillard H, Cordier S, Jégou B, Thome JP, Blanchet P (2010) Chlordecone exposure and risk of prostate cancer. J Clin Oncol 28:3457-3462. doi:10.1200/JCO.2009.27.2153

New MB (2002) Farming freshwater prawns: a manual for the culture of the giant river prawn (Macrobrachium Rosenbergii)., Food and Agriculture - Organization of the United Nations

Newhouse K, Berner T, Mukerjee D, Rooney A (2009) IRIS toxicological review of chlordecone (Kepone), U.S. Environmental Protection Agency. U.S. Environmental Protection Agency, Washington DC

Oberdörster E, Rice CD, Irwin LK (2000) Purification of vitellin from grass shrimp Palaemonetes pugio, generation of monoclonal antibodies, and validation for the detection of lipovitellin in Crustacea. Comp Biochem Physiol Part C Pharmacol Toxicol Endocrinol 127: 199-207. doi:10.1016/S0742-8413(00)00146-8

Qiu G-F, Zheng L, Liu P (2008) Transcriptional regulation of ferritin mRNA levels by iron in the freshwater giant prawn, Macrobrachium rosenbergii. Comp Biochem Physiol B Biochem Mol Biol 150:320-5. doi:10.1016/j.cbpb.2008.03.016

Raikhel AS, Dhadialla TS (1992) Accumulation of yolk proteins in insect oocytes. Annu Rev Entomol 37:217-51. doi:10.1146/annurev. en.37.010192.001245

Rodriguez EM, Medesani DA, Fingerman M (2007) Endocrine disruption in crustaceans due to pollutants: a review. Comp Biochem Physiol - A Mol Integr Physiol 146:661-671. doi:10.1016/j. cbpa.2006.04.030

Roth Z, Khalaila I (2012) Identification and characterization of the vitellogenin receptor in Macrobrachium rosenbergii and its expression during vitellogenesis. Mol Reprod Dev 79:478-487. doi:10.1002 /mrd.22055 
Ruijter JM, Ramakers C, Hoogaars WMH, Karlen Y, Bakker O, van den Hoff MJB, Moorman AFM (2009) Amplification efficiency: linking baseline and bias in the analysis of quantitative PCR data. Nucleic Acids Res 37:e45. doi:10.1093/nar/gkp045

Ruttanakorn S, Meeratana P, Chetawan K, Hanna P (2014) Induction of ovarian development and sex differentiation in the giant freshwater prawn Macrobrachium rosenbergii, by serotonin, methyl farnesoate, and phytoecdysone. J Sci Technol Humanit 11:77-86

SANCO/12571/2013 European commission, n.d. Guidance document on analytical quality control and validation procedures for pesticide residues analysis in food and feed. Health and Consumer Protection-Safety of the food chain: Chemicals, contaminants, pesticides

Sanders MB, Billinghurst Z, Depledge MH, Clare AS (2005) Larval development and vitellin-like protein expression in Palaemon elegans larvae following xeno-oestrogen exposure. Integr Comp Biol 45:51-60. doi:10.1093/icb/45.1.51

Sappington TW, Raikhel AS (1998) Molecular characteristics of insect vitellogenins and vitellogenin receptors. Insect Biochem Mol Biol 28:277-300. doi:10.1016/S0965-1748(97)00110-0

Schonbaum CP, Lee S, Mahowald AP (1995) The Drosophila yolkless gene encodes a vitellogenin receptor belonging to the low density lipoprotein receptor superfamily. Proc Natl Acad Sci 92:1485-1489. doi:10.1073/pnas.92.5.1485

Scott AP (2013) Do mollusks use vertebrate sex steroids as reproductive hormones? II. Critical review of the evidence that steroids have biological effects. Steroids 78:268-81. doi:10.1016/j. steroids.2012.11.006

Shrivastava S, Princy SA (2014) Crustacean hyperglycemic hormone family neurohormones: a prevailing tool to decipher the physiology of crustaceans. Indian J Mar Sci 43:434-440

Snegaroff J (1977) Les résidus d'insecticides organochlorés dans les sols et les rivières de la région bananière de Guadeloupe. Phytiatr Phytopharm 26:251-268

Snyder MJ, Mulder EP (2001) Environmental endocrine disruption in decapod crustacean larvae: hormone titers, cytochrome P450, and stress protein responses to heptachlor exposure. Aquat Toxicol 55: 177-190. doi:10.1016/s0166-445x(01)00173-4

Soroka Y, Milner Y, Sagi A (2000) The hepatopancreas as a site of yolk protein synthesis in the prawn Macrobrachium rosenbergii. Invertebr Reprod Dev 37:61-68. doi:10.1080 /07924259.2000.9652400

Subramoniam T (2011) Mechanisms and control of vitellogenesis in crustaceans. Fish Sci 77:1-21. doi:10.1007/s12562-010-0301-z

Sumpter JP, Jobling S (1995) Vitellogenesis as a biomarker for estrogenic contamination of the aquatic environment. Environ Health Perspect 103:173-178. doi:10.1289/ehp.95103s7173
Techa S, Chung JS (2015) Ecdysteroids regulate the levels of moltinhibiting hormone $(\mathrm{MIH})$ expression in the blue crab, Callinectes sapidus. PLoS One 10:e0117278. doi:10.1371/journal. pone. 0117278

Techa S, Chung JS (2013) Ecdysone and retinoid-X receptors of the blue crab, Callinectes sapidus: cloning and their expression patterns in eyestalks and Y-organs during the molt cycle. Gene 527:139-153. doi:10.1016/j.gene.2013.05.035

Thomson SA, Baldwin WS, Wang YH, Kwon G, LeBlanc GA (2009) Annotation, phylogenetics, and expression of the nuclear receptors in Daphnia pulex. BMC Genomics 10:500. doi:10.1186/1471-2164$10-500$

Thornton J, Need E, Crews D (2003) Resurrecting the ancestral steroid receptor: ancient origin of estrogen signaling. Science 301:1714-7. doi:10.1126/science. 1086185

Tinikul Y, Joffre Mercier A, Soonklang N, Sobhon P (2008) Changes in the levels of serotonin and dopamine in the central nervous system and ovary, and their possible roles in the ovarian development in the giant freshwater prawn, Macrobrachium rosenbergii. Gen Comp Endocrinol 158:250-258. doi:10.1016/j.ygcen.2008.07.009

Tiu SHK, Benzie J, Chan S-M (2008) From hepatopancreas to ovary: molecular characterization of a shrimp vitellogenin receptor involved in the processing of vitellogenin. Biol Reprod 79:66-74. doi:10.1095/biolreprod.107.066258

Tokishita S-I, Kato Y, Kobayashi T, Nakamura S, Ohta T, Yamagata H (2006) Organization and repression by juvenile hormone of a vitellogenin gene cluster in the crustacean, Daphnia magna. Biochem Biophys Res Commun 345:362-70. doi:10.1016/j. bbrc.2006.04.102

Tyler CR, van der Eerden B, Jobling S, Panter G, Sumpter JP (1996) Measurement of vitellogenin, a biomarker for exposure to oestrogenic chemicals, in a wide variety of cyprinid fish. J Comp Physiol B 166:418-426. doi:10.1007/BF02337886

Young NJ, Webster SG, Rees HH (1993) Ecdysteroid profiles and vitellogenesis in Penaeus monodon (Crustacea: Decapoda). Invertebr Reprod Dev 24:107-117. doi:10.1080/07924259.1993.9672340

Zhong L, Yuan L, Rao Y, Li Z, Zhang X, Liao T, Xu Y, Dai H (2014) Distribution of vitellogenin in zebrafish (Danio rerio) tissues for biomarker analysis. Aquat Toxicol 149:1-7. doi:10.1016/j. aquatox.2014.01.022

Zou E (2005) Impacts of xenobiotics on crustacean molting: the invisible endocrine disruption. Integr Comp Biol 45:33-38. doi:10.1093 /icb/45.1.33

Zou E, Fingerman M (1999) Effects of exposure to diethyl phthalate, 4(tert)-octylphenol, and 2,4,5-trichlorobiphenyl on activity of chitobiase in the epidermis and hepatopancreas of the fiddler crab, Uca pugilator. Comp Biochem Physiol Part C Pharmacol Toxicol Endocrinol 122:115-120 